\title{
The Effect of the Utilization of School Library and Reading Interest on Student Learning Achievement Class IX in Junior High School 3 Kayuagung
}

\author{
Sumartin ${ }^{1 *}$, Missriani ${ }^{2}$, Dessy Wardiah ${ }^{2}$
}

\author{
${ }^{1}$ Junior High School 3 Kayuagung \\ ${ }^{2}$ Universitas PGRI Palembang \\ *Corresponding author. Email: yantiy03@gmail.com
}

\begin{abstract}
The use of the library can be a process to familiarize students with reading, and to generate student interest in reading. The use of libraries and reading interest is closely related to student achievement. When students make good use of the library, they have a high reading interest and students are always interested in digging up information through the library's book collection. The problem faced at SMP Negeri 3 Kayuagung is the low number of student visits to the library to read and study, coupled with online learning during the Covid -19 pandemic. This study aims to find out how much influence the use of libraries and interest in reading has on student achievement at SMP Negeri 3 Kayuagung. This research uses quantitative methods using multiple regression analysis. The population in this study were all students of class IX SMP Negeri 3 Kayuagung. The number of samples used in this study were 60 students, who were selected using a random sampling technique. The research data were obtained by using a questionnaire for the variables of library use and reading interest, while student achievement was obtained using odd UTS scores. The results show 1) There is a significant influence between the use of the school library on learning achievement, as evidenced by the results of linear regression analysis, the sig value is obtained. $=0.000<$ from $\alpha(0.05), 2)$ There is a significant influence between students' reading interest on learning achievement as evidenced by the results of linear regression analysis, the sig value is obtained. $=0.000<$ from $\alpha(0.05)$.
\end{abstract}

Keywords: Library, Reading Interest, Achievement.

\section{INTRODUCTION}

In the Law of the Republic of Indonesia number 20 of 2003 in Hartono's book on the National Education system Chapter I, article reads. "Consciously planned business education to create an atmosphere of learning and the learning process of students to actively develop their own potential to have religion, self-control, personality, noble moral intelligence, and skills needed by themselves, society, nation and state".

Conscious and planned efforts for the implementation of truth-oriented education. The implementation of education is not only results-oriented, but also pays attention to the processes that occur during educational activities. The learning process is directed so that students can develop their potential, this means that education must be oriented towards students so that their potential can be explored and developed. Fananie [1] said that education is not only in the hands of teachers at school, parents at home, but all things that can affect the spiritual goodness of humans from childhood to adulthood to become parents who can receive education in a humane and mindset which is healthy.

Fananie [1] also argues, education aims to help direct the path of kindness for children, adolescents, parents or anyone else in every deed, word and heart.

Hamalik [2] argues, the purpose of education is a set of educational outcomes achieved by students after the implementation of educational activities. Such as tutoring, Bimtek learning, research, educational seminars, courses aimed at achieving educational goals.

The quality of education is closely related to the learning achievement of students. Measurement standards show the ability of students to understand the learning process which is known from their learning achievement. The learning process is a process created for the benefit of students involving body and soul [3]. 
Achieving high learning achievement is not an easy thing, because learning success is influenced by 4 (four) aspects, namely. 1) aspects of knowledge to determine how students can demonstrate understanding. 2) aspects of the ability to think, to find out how students can think: 3) aspects of skills, to find out what students can do and indicate changes. and 4) behavioral aspects, to find out how student behavior shows positive changes in class.

Student achievement is influenced by various factors. As follows. a) Internal factors include. physical factors (health and disability), psychological factors (intelligence, attention, interests, talents, readiness; and fatigue factors (consisting of fatigue of human services and spiritual fatigue); and b) External factors consist of: financial factors (parental methods ), and school factors such as teaching methods, curriculum, teacher-student relationships, student-student relationships, school discipline, school time learning tools, learning standards for size, building conditions, learning methods and [4] .

In this study, the writing will try to discuss the factors that affect student achievement, namely those included in the external factors are the use of the school library, and the internal factors are reading interest and student achievement.

One of the development priorities in education is the use of school rotations related to the learning process carried out by educational institutions. Organizing the school library is an effort to maintain and increase the effectiveness and efficiency of the learning process [5].

A building (building) or room to store collection books, recordings and so on which plays an important role in promoting the reading activities of students to read at school to improve learning achievement as a primary source. It is better if the library in the school can create a conducive environment, the point is to encourage students to read. Some things that must be provided by the school library, such as comfortable seating, colorful wall paint, a computer connected to the internet, a printed floor carpet [6].

Darmono [7] argues that the school library is one of the educational facilities and infrastructure that will support student activities which play an important role in spurring the achievement of educational goals in schools. Libraries not only store and collect library materials that are used as reference materials, but it is hoped that students will gradually have a passion for reading which is a fundamental tool for learning both at school and outside of school. This needs to be supported by the provision of facilities and services in the library, such as comfortable reading and learning facilities, a good collection of books, literature, journals, magazines, newspapers, and some research results.

The success of his learning achievement is influenced by the use of the [8]. The condition of the infrastructure owned by the library will affect the visitor level of students and teachers. Currently, many libraries have not been managed seriously, so that there are still many students and teachers who have not used the library as a place to read and study. This shows that students are less active in independent learning, so that in the end the bias has an effect on student achievement.

Reading is one way to add and improve knowledge, broaden views, enrich information and stimulate the emergence of new ideas. Reading interest is related to learning outcomes, because by having high reading interest, knowledge becomes more. Reading interest in the Indonesian dictionary is a strong heart toward something, the 2013 curriculum hopes for a reading culture as an effort to foster interest in reading in educational units in accordance with the idea of the Minister of Education and Culture. An integrative thematic-based curriculum will force teachers to add coffers of insight as a source of learning [9].

Purwanto [10] argues, the process of getting students accustomed to reading can be trained by giving assignments oriented to encourage students to visit the library in search of reference sources. Therefore, in the learning process, teachers should be able to direct students' skills in terms of fostering student reading interest so that students can become independent in seeking knowledge in educational institutions, it is hoped that the learning achievement achieved can be better.

During this pandemic, their online learning with permission and accompanied by parents of several students came to look for books related to school work, on the condition that they comply with health protocols, including wearing masks, washing hands with soap, using Hansanitazer, keep your distance and not. may gather, and the number of students is still limited on a scheduled basis. Local authorities may grant permission to study face-to-face but remain vigilant.

Based on field observations that the author met. That the school library at SMP Negeri 3 Kayuagung has a very strategic location in its own room. The building is located between the study room and the teacher / administration office which is well laid out, even though the building is still of an old standard size, it does not rule out the possibility for students to read inside or outside the library building. Outside the library building has a large yard, under the shady trees a literacy corner has been installed, so that students feel comfortable to discuss and read learning issues. In the literacy corner we also provide several collection books, magazines, newspapers, and others which are changed every day.

Thus, the reading culture of SMP Negeri 3 Kayuagung students can improve. The books that are arranged on a used cupboard are also used as a place to store books. The number of books in the collections 
compiled reached more than 7000 copies, not to mention the textbooks, teacher's handbooks, and student books. The library room facilities are still inadequate to accommodate many students visiting the library. This is because the library room is still $84 \mathrm{~m} 2$ in size, while the standard size of the library room is at least $105 \mathrm{~m} 2$ for junior high school level. But now with class 21 and nearly 700 people it is certainly not feasible anymore.

Conditions that affect reading interest to be even better, are really far from expectations and create student reading interest, coupled with the lack of school motivation to read. How do students want to use the library, if the teachers do not read and invite students to like reading. In accordance with the vision of the library of SMP Negeri 3 Kayuagung "multiplying myriad knowledge by reading". Meanwhile, the mission of the library is "to cultivate students to love books, to create students with brilliant achievements, and to create a spirit of achievement". From the Vision and Mission, the hope of a culture of reading is reflected.

In connection with the author did it in August 2020 at SMP Negeri 3 Kayuagung, what is owned is good enough. There is already an organizational structure consisting of a person in charge, the head of the library and assisted by library management members. Likewise, the reading room facilities and book collections provided in the library are quite adequate. Seats are also available in the library room, a large collection of books ranging from class 100 general works to class 900 (history, earth science), reference books and magazines. While the room consists of one classroom with tables and chairs for reading, it is still not enough to accommodate many students visiting the library. Students who visit the library every day are not more than 50 students, So it can be assumed that library administration has not been well documented. Furthermore, library administrators are teachers who are appointed to manage libraries with educational backgrounds who are not librarians and it is felt that the number still needs to be increased to provide library services.

The limited library space that is owned for reading, room for playing video lessons (audio visual), story space (poetry, drama, pantonym, interviews), multipurpose room and so on. To manage books, there should be a separate room so as not to disturb the visitors. Thus the visitors are not comfortable reading books in the library.

In line with the previous discussion, the role of library use for educational institutions in improving student achievement at SMP Negeri 3 Kayuagung is strongly influenced by reading interest and motivating learning from students themselves. The higher the students' reading interest, the more knowledge they will gain and will support their learning achievement. Likewise with the learning motivation possessed by grade IX students of SMP Negeri 3 Kayuagung, of course, will affect the achievement of their learning achievement levels. The more motivated to learn, students will have the persistence to seek knowledge related to learning activities so that the learning achievement achieved will certainly be good too.

\section{METHODS}

This it uses a quantitative approach. Quantitative, is a research method that is systematic and uses mathematical models. A quantitative approach is to see the effect partially between the existing variables (Sugiyono, 2012). The quantitative research variables tested in this study consisted of the use of the school library (X1) on reading interest (X2), the use of school library research $(\mathrm{X} 1)$ on student achievement (Y), reading interest $(\mathrm{X} 2)$ on student achievement $(\mathrm{Y})$, while testing the hypothesis together (simultaneously), namely the use of the school library (X1) and reading interest (X2) on student achievement (Y), then all the data obtained were processed and processed with quantitative analysis.

\section{RESULTS AND DISCUSSION}

The results of hypothesis testing show the significance value of multiple linear regression of 0.000 . Based on the hypothesis criteria, if the significance is $\leq$ $\alpha(0.05)$, it can be concluded that there is a significant influence between library use and reading interest on achievement. equally influential on student achievement at SMA Negeri 1 Tanjung Raja. Good library management can motivate students to visit the library and even increase reading interest which in turn can have an impact on student learning achievement.

Overall, the influence of library use and reading interest gave a large contribution of around $80.6 \%$. Much different from previous research, namely which found the effect of library use and reading interest on learning achievement in craft and entrepreneurship lessons by $14.8 \%$. Meanwhile, research by [11] found that the magnitude of the influence of library management and reading interest was $9.2 \%$ on student achievement and the remaining $81.8 \%$ was determined by other variables not studied.

Rahadian [12] state that libraries have a role in increasing the culture of students' love of reading argues that the use of learning resources provided by the library in the learning process has a big effect on increasing learning achievement because students are motivated to read books. The availability of school libraries with good management which has an impact on increasing interest in reading which ultimately increases student achievement, meaning that the goals of the library have been achieved. 
The results of hypothesis testing are obtained sig. for the library use variable (X1) 0.05 is the same as the $\alpha$ value (0.05). This means that the use of the library (X1) has an effect on learning achievement (Y). If you look at the results of data collection on variable $\mathrm{X} 1$, the most widely used form of library use is to do the assignments of the teacher, so it is natural that the library is predicted not to play a significant role compared to student interest in reading.

Zulkarnain [13] states that good library services will be useless if students' reading interest is still low. In addition, although reading interest is high, students tend to read fiction books, it does not have an impact on increasing student learning achievement. In addition to the availability of books that are interesting to read, literacy shifts and the way students gather information are also influential. The ease of obtaining information through the internet and social media cannot be avoided, and makes libraries the last resort for finding information.

Mayora [14] describe several strategies that can be done to overcome the problem of low library interest and use.

a. First, the librarian must provide a library-specific internet service with a library page that contains all information about all collections and information in the library.

b. Librarians must still pay attention to what is needed by the user, besides that the information must still be in accordance with the provisions of the special library itself, namely the information must be related to library functions

c. After providing services via the internet and improving the collection, the following things librarians can do so that the library can run according to its function is by providing optimal service.

The challenge of libraries for education in the 4.0 era itself is to organize literacy activities that are interesting and fun. Hidayah [15] argues that there are two elements that support the formation of a social and affective environment that supports literacy in schools, namely the optimization of libraries and the participation of stakeholders in the success of literacy activities in schools. Batubara [16] describes one of the methods used to build information literacy in libraries with user education.

The stages of education for users or students that can be carried out by library managers are as follows.

a. First of all, they are made aware of the extent and number of library resources, services, and information sources available to users. b. Second, it is taught how to use library resources, services, and information sources with the aim of introducing the existence of the library, explaining information tracking mechanisms and teaching users how to exploit the available resources.

Based on the results of the partial influence analysis, reading interest makes a significant contribution to student achievement. If a student has a high reading interest, especially in textbooks or other books that support knowledge, it will automatically have an impact on increasing learning achievement. This is in accordance with the opinion of Marlina [17] which states that high reading interest can make students have broad insights and better know and understand the subject matter which in turn can affect learning achievement.

In addition, Sadirman [18] states that the learning process will run smoothly and pleasantly and even get satisfying results when accompanied by high interest. In addition, Diem [6] states that by reading students can get information, improve ways of thinking, and generate ideas and can solve various problems in lessons. In line with the opinion of Ginasari [19], if interest in reading is aimed at increasing knowledge, it will contribute positively to learning achievement.

The link between reading interest and achievement is that reading interest will get results, both information, understanding, skills knowledge, motivation and facts as presented in the reading material. The things that have been read are very useful for the self-development of the reader, the family and the wider community. In addition, reading results will also develop an attitude of respect for time, an objective attitude in discussing a problem, attaching importance to facts or information, and so on.

\section{CONCLUSION}

Based on the findings and testing of the research hypothesis, the research conclusions were obtained, among others. 1) There is a significant influence between the use of the school library on the learning achievement of Class IX students of SMP Negeri 3 Kayuagung. 2) There is a significant influence between students' interest in reading on student achievement of Class IX SMP Negeri 3 Kayuagung. 3) The use of the school library and students' reading interest together have a significant effect on the learning achievement of Class IX students of SMP Negeri 3 Kayuagung.

Based on the conclusions that have been described, the author has several suggestions as follows. 1) So that the school library can create good management which results in increased reading interest which ultimately increases student learning achievement. Therefore, it is necessary to improve the quality and managerial 
libraries at SMP Negeri 3 Kayu Agung. 2) In order to aggressively educate students and teachers in utilizing library collections and facilities. Thus it can increase students' interest in reading, and students can use the library as a means of achieving their learning achievement. 3) So that literacy activities can be carried out routinely through the library. Basically, interest in reading is a combination of desire, will, and motivation. Literacy activities can be a medium to foster motivation and desire to read,

\section{REFERENCES}

[1] Fananie, Z. (2011). Modern Educator Guidance. Solo: PT Tiga Serangkai Pustaka Mandiri.

[2] Hamalik, O. (2013). Curriculum and Learning. Jakarta: Earth Literacy.

[3] Djamarah, S. B. (2011). Psychology of Learning. Jakarta: Rineka Cipta.

[4] Slameto. (2010). Learning and the factors that influence it. Jakarta: Rineka Cipta.

[5] Sinaga, D. (2011). Managing School Libraries. Bandung: Vessel.

[6] Diem, C. D. (2011). Libraries, Libraries, and Literature. Palembang: Sriwijaya University.

[7] Darmono. (2012). School Libraries approach to management aspects and work procedures. Jakarta: PT. Grasindo.

[8] Sudarnoto, A. H. (2012). Library and Education Mapping the Role of Libraries in Teaching and Learning Process. Jakarta: Faculty of Adab and Humanities UIN Jakarta.

[9] Muksin \& M. M. (2020). Literacy Movement to Educate the Country. Yogyakarta: Aswaja Pressindo.

[10] Purwanto. M. N. (2016). Evaluation of Learning Outcomes. Yogyakarta: Learning Library.
[11] Zuriyati, H. Harapan E. \& Missriani M. (2020). The Influence of Library Management and Reading Interest on Student Achievement. The Light of Education, 6 (1), 13-24.

[12] Rahadian, G., Rohanda, R., \& Anwar, RK. (2014). The Role of School Libraries in Improving Reading Culture. Journal of Information \& Library Studies, 2 (1), 47-56.

[13] Zulkarnain, A. (2018). The Use of Graphic Design in Hidayatullah Magazine as a Media of Da'wah to Attract Reading Interest in Mad'u in Bandar Lampung (Doctoral Dissertation. UIN Raden Intan Lampung).

[14] Mayora, H., \& Nelisa, M. (2013). Strategies for Improving Library Use in the Special Library of West Sumatra Province Dprd Secretariat. Library and Archives Information Science, 2 (1), 380-388.

[15] Hidayah, L. (2017). Implementation of Literacy Culture in Elementary Schools through Optimization of Libraries: Case Study in public elementary schools in Surabaya. Juke (Journal of Food Security), 1 (2), 48-58

[16] Batubara, AK (2015). Information Literacy in the Library. Iqra: Journal of Library and Information Science (E-Journal), 9 (1), 43-56.

[17] Marlina, L. (2017). The Relationship between Reading Interest and Learning Motivation with Economic Learning Outcomes of Class XI IPAS SMA 10 Pakanbaru. Pekbis Articles and Journal Vol. 9, No.1, March 2017: 33-47

[18] Sadirman, AM. (2010). Interaction and Teaching and Learning Motivation. Jakarta: Raja Grapindo Persada.

[19] Ginasari, O. (2016). The Relationship between Library Service and Reading Interest with Student Achievement in Educational Administration Department, Faculty of Education, State University of Malang. Essay. 